UDC 669.295-157.8'669.781

K.O. Kostyk, $\mathrm{PhD}$, Assoc.Prof.,

V.O. Kostyk, PhD, Assoc.Prof.

National Technical University “Kharkiv Polytechnic Institute”, 21 Frunze Str., 61002 Kharkiv, Ukraine; e-mail: eklitus@yandex.ru

\title{
NANODISPERSED BORIDING OF TITANIUM ALLOY
}

К.О. Костик, В.О. Костик. Нанодисперсне борування титанового сплаву. Задача підвищення експлуатаційної надійності машин набуває все більшого значення у зв'язку зі збільшенням механічних, теплових та інших видів навантажень на деталі. Для деталей машин, руйнування яких починається з поверхні, розроблено велику кількість методів поверхневого зміцнення, найбільш перспективними з яких є методи хіміко-термічної обробки. Мета: Метою роботи є дослідження впливу режимів борування на структуру і властивості титанового сплаву. Матеріали і методи: Матеріалом дослідження в даній роботі є титановий сплав ВТ3-1. Борування проводили в порошкоподібних нанодисперсних сумішах на основі боровмістких речовин. Результати: Встановлено, що борування 3 паст забезпечує отримання твердості поверхні в межах $30 \ldots 29$ ГПа 3 пониженням іiі до $27 . .26$ ГПа по шару до перехідної зони (з загальною товщиною до 110 мкм), що пов'язане зі зміною фазового складу самого шару, в якому формуються бориди титану $\mathrm{Ti}_{2} \mathrm{~B}, \mathrm{TiB}, \mathrm{TiB}_{2}$. Збільшення часу хіміко-термічної обробки від 15 хвилин до 2 годин приводить до зростання борованого шару (30...110 мкм) і перехідної зони (30..190 мкм). Висновки: Завдяки використанню нанодисперсного боровмісного порошку тривалість насичення бором скорочується в $2 . .3$ рази, що дозволить зекономити час та електроенергію. Розроблений оптимальний режим борування для титанового сплаву ВТ3-1 дозволяс отримати необхідні експлуатаційні властивості та суміщати насичення поверхневого шару атомарним бором з гартуванням.

Ключові слова: борування, титановий сплав, мікроструктура, дифузійний шар, поверхнева твердість.

K.O. Kostyk, V.O. Kostyk. Nanodispersed boriding of titanium alloy. The problem of improving the operational reliability of machines is becoming increasingly important due to the increased mechanical, thermal and other loads on the details. There are many surface hardening methods for machines parts which breakdown begins with surface corruption. The most promising methods are chemical-thermal treatment. Aim: The aim of this work is to study the impact of boriding on the structure and properties of titanium alloy. Materials and Methods: The material of this study is VT3-1 titanium alloy. The boriding were conducted using nanodispersed powder blend based on boric substances. Results: It is established that boriding of paste compounds allows obtaining the surface hardness within $30 . .29 \mathrm{GPa}$ and with declining to $27 \ldots 26 \mathrm{GPa}$ in layer to the transition zone (with total thickness up to $110 \mu \mathrm{m}$ ) owing to changes of the layer phase composition where $\mathrm{Ti}_{2} \mathrm{~B}, \mathrm{TiB}, \mathrm{TiB}_{2}$ titanium borides are formed. The increasing of chemical-thermal treatment time from 15 minutes to 2 hours leads to thickening of the borated layer $(30 \ldots 110 \mu \mathrm{m})$ and transition zone $(30 \ldots 190 \mu \mathrm{m})$. Conclusions: Due to usage of nanodispersed boric powder, the boriding duration is decreasing in $2 . . .3$ times. This allows saving time and electric energy. The developed optimal mode of boriding the VT3-1 titanium alloy allows obtaining the required operational characteristics and to combine the saturation of the surface layer with atomic boron and hardening.

Keywords: boriding, titanium alloy, microstructure, diffusion layer, surface hardness.

Introduction. The problem of improving the operational reliability of machines is becoming increasingly important due to the increased mechanical, thermal and other loads on the details. There are many surface hardening methods, which based on the coating or on the change of surface condition, were developed for machines parts which breakdown begins with surface corruption. The most promising methods are chemical-thermal treatment. It means the formation of chemical compounds on the components' surface.

The chemical-thermal treatment of metals and alloys hardening are used to change the chemical composition, structure and properties of the surface layer. It becomes available due to the diffusion saturation of metals and alloys with non-metals (C, N, B, Si, etc.) or metals (Al, Cr, Zn, etc.). Diffusion surface layers, obtained as a result of the chemical-thermal treatment, have a number of advantages. Their cohesive strength to the base metal significantly exceeds the strength of other types of coatings, and a gradual change in the chemical composition by the diffusion layer depth creates a smooth change of properties from surface to core of a component. The composition, structure, physical and chemical properties of the diffusion layer is determined by the composition and properties of a saturation environment and the initial state of the material, temperature and duration of chemicalthermal treatment.

Materials and Methods. One of the most effective means of improving the lifetime of machine parts is their surface hardening, which significantly increases the wear resistance, durability, resistance to components' destruction. There are various methods of surface hardening: surface heat treatment,

DOI 10.15276/opu.3.47.2015.04

(C) 2015 The Authors. This is an open access article under the CC BY license (http://creativecommons.org/licenses/by/4.0/). 
work hardening, electric spark machining, surfacing, welding-on and a variety of chemical-thermal processing $[1,2]$.

Recently, the chemical-thermal treatment became widely used to improve properties of the surface layers of different metals and alloys based on titanium, molybdenum, niobium, tantalum, zirconium, tungsten, cobalt, nickel, copper and others. The Diffusion saturation of these materials with different elements is designed to increase hardness, wear resistance, anti-friction properties, heat resistance, hot resistance, corrosion resistance and other performance properties. The chemical-thermal treatment of the listed metals is performed at rather high temperature and long-term keeping, which often leads to products' core degradation, their deformation. The chemical-thermal treatments require the use of protective media, which are technologically complex, time-consuming and economically costly $[2 \ldots 4]$.

The chemical-thermal treatment of nonferrous metals and alloys, which undergo allotropic or phase transformations during heating and characterized by a wide temperature interval of existence of high-temperature modification, is one of the most common methods to improve the durability of structures' components. This is true especially for titanium, zirconium, cobalt, tungsten and their alloys. Titanium and its alloys, having a low density, high specific mechanical properties and specific strength, have high corrosion resistance (resistance to intergranular and other types of corrosion). The disadvantage of titanium alloys is their active interaction with atmospheric gases, tendency to hydrogen embrittlement, low scaling resistance up to $550 \ldots 600^{\circ} \mathrm{C}$. Nitrogen, carbon, hydrogen and oxygen, even in very small quantities, greatly strengthen titanium, but they reduce its ductility, corrosion resistance, impair weldability. Without being hardened, the titanium alloys have low wear resistance properties and a tendency to stick and finning at work in friction units. Titanium doping and titanium alloys heat treatment do not significantly alter their durability. Therefore, the chemical-thermal treatment is the most promising hardening method to improve the titanium alloys performance properties. Titanium and its alloys are badly machined, but satisfactory processed by pressure. The mentioned alloys castings are recommended to get in vacuum using a vacuum arc remelting. Titanium exists in two allotropic forms. Below $882,5^{\circ} \mathrm{C}$, the element exists in the stable $\alpha$-form, with a closepacked hexagonal lattice ( $a=2,951 \AA, c=4,679 \AA)$; above this temperature, the element takes the $\beta$ form, with a body-centered cubic lattice $(a=3.269 \AA)$.

By manufacturing technology, titanium alloys are classified into deformable alloys, casting alloys, powder alloys; by physicochemical and mechanical properties — on high- and standardhardness titanium alloys, high-ductile alloys, heat-resistant alloys, and corrosion resistant alloys.

The boriding method is used to increase hardness, wear resistance and heat resistance of alloys surface. The boriding is the process where boron atoms are diffused into the surface of metals or alloys [4...6].

Boriding of titanium can be done in a vacuum furnace in powders of amorphous boron or in the vessel in a melt of borax with or without electrolysis, or in a powder of $84 \%$ boron carbide and $16 \%$ borax in a hydrogen flow. For all the processes, the boriding temperature is $1000 \ldots 1200{ }^{\circ} \mathrm{C}$; dwell time - from 4 to 8 hours; herewith the diffusion layers have a thickness of $8 \ldots 13$ microns with microhardness of $29 \ldots 31 \mathrm{GPa}$.

Borated layer microstructure depends on the boriding conditions. External zone of the borated layer - $\mathrm{TiB}_{2}$, and the internal one - $\mathrm{TiB}$. Durability of components made from borated titanium alloys is $5 \ldots .20$ times higher than the steel cemented.

Mostly, titanium is borided in powders of amorphous boron or boron carbide [7...8].

The diffusion layers, which formed by boriding, are significantly enhance the properties of titanium alloys [1...8]. Titanium alloys, because of their physical and mechanical properties, are the versatile construction material that combines the absence of cold brittleness, high corrosion resistance of the best copper-nickel alloys and stainless steels; nonmagnetic properties, hardness of titanium alloys are higher than those in most construction materials. Therefore, the application of titanium alloys is effective in aviation, space construction, chemical industry, shipbuilding and others. 
The processing of titanium alloys of all grades involves the cutting (turning, drilling, etc.), including gas cutting; it also involves all kinds of argon arc welding. This makes able to use titanium alloys for the manufacture of a variety of complex parts, units and assemblies.

Lütjering and Williams [1] recommended to replace details that are made of steel, which often fail due to fatigue damage, with the details made of titanium alloys, such as VT3-1 titanium alloy (Table 1).

Table 1

The application of VT3-1 titanium alloy

\begin{tabular}{c|c|c|c}
\hline Constructions & $\begin{array}{c}\text { Types of steel used in } \\
\text { construction }\end{array}$ & $\begin{array}{c}\text { Types of steel recom- } \\
\text { mended in construction }\end{array}$ & $\begin{array}{c}\text { Justification for the use } \\
\text { of VT3-1 alloy }\end{array}$ \\
\hline Bolt, connecting rod nut & $45 \mathrm{GA}$ & VT3-1, VT8 & $\begin{array}{c}\text { Increased reliability and } \\
\text { durability at the work } \\
\text { with high speed }\end{array}$ \\
\hline Piston pin & $12 \mathrm{KhN3A}$ & VT3-1, VT8 & $\begin{array}{c}\text { Increased lifetime and } \\
\text { durability }\end{array}$ \\
\hline Bocker tappet & $40 \mathrm{Kh}$ & VT3-1, VT8 & $\begin{array}{c}\text { Increased durability, } \\
\text { reduced the overall ma- } \\
\text { chine weight }\end{array}$ \\
\hline
\end{tabular}

The aim of this work is to study the impact of boriding on the structure and properties of titanium alloy.

Materials and Methods. The studied material and boriding method. The studied material in this research work is VT3-1 titanium alloy containing the necessary alloy elements to form borides during boriding the surface layer of samples. Before the chemical-thermal treatment the studied samples surface was cleaned: oxide scale, rust, grease and other contaminants were removed. Then the surface was polished and smoothed with the followed degreasing by 96-percent alcohol.

The boriding were conducted using nanodispersed powder blend based on boric substances. The components were dry mixed in a special mixer, then bounding agents added to the required consistency. The paste layer was applied 2...3 times on the prepared samples with drying in the drying chamber at the temperature of $140{ }^{\circ} \mathrm{C}$ for $30 \ldots 40$ minutes until the paste dries. Further on, the samples that have been stirred with the mixture were placed in the crucible and then - in a thermal furnace for $15 \ldots 120 \mathrm{~min}$ at $900{ }^{\circ} \mathrm{C}$. The chemical-thermal treatment of samples was conducted in a chamber furnace.

The low-temperature tempering was held after boriding at a temperature of $200{ }^{\circ} \mathrm{C}$ to remove the internal stresses.

Analysis of nanotechnology impact on borated layer structure of VT3-1 titanium alloy formation. The titanium alloy structure may be a factor intensifying the boriding process, although there is no consensus about the nature of its impact on the process of diffusion saturation of alloys with interstitial elements.

Metallographic observation showed that the alloy structure in its initial state is heterogeneous and consists of fragments - parallel plates of $\alpha$-phase ( $92 \%)$, which are separated by layers of $\beta$-phase $(\sim 8 \%)$, which partially collapsed. When heated for quenching up to a temperature of $900{ }^{\circ} \mathrm{C}$, the alloy structure does not change essentially (Fig. 1): narrow and long $\beta$-phase spots, trapped between the plates of the primary $\alpha$-phase, remain the shape due to this rigid frame. But starting with the temperature of $970{ }^{\circ} \mathrm{C}, \alpha$-phase plates disappear, and $\beta$-phase spots can grow freely, acquiring the form of 
large polyhedra. Therefore, the titanium alloy quenching was conducted at $900{ }^{\circ} \mathrm{C}$, namely at the temperature of boriding.

Source structural condition not only determines the diffusion rate of boron, but also affect the mechanism of saturation process. In metastable solid solutions $\left[\alpha^{\prime \prime}\left(\alpha^{\prime}\right)+\alpha+\beta\right.$ and $\left.\alpha^{\prime}\right]$, which obtained in the VT3-1 titanium alloy as a result of heat treatment, the boron diffusion is carried out at high speed, and sometimes there is no possibility to achieve critical concentration necessary for the boride zone formation in the sample's surface layer. In this case of hardening, the hardened zone is a solid solution of boron in $\alpha$-titanium and a small amount of titanium borides $\mathrm{TiB}_{2}$ and $\mathrm{TiB}$ in the surface layer (Fig. 2).

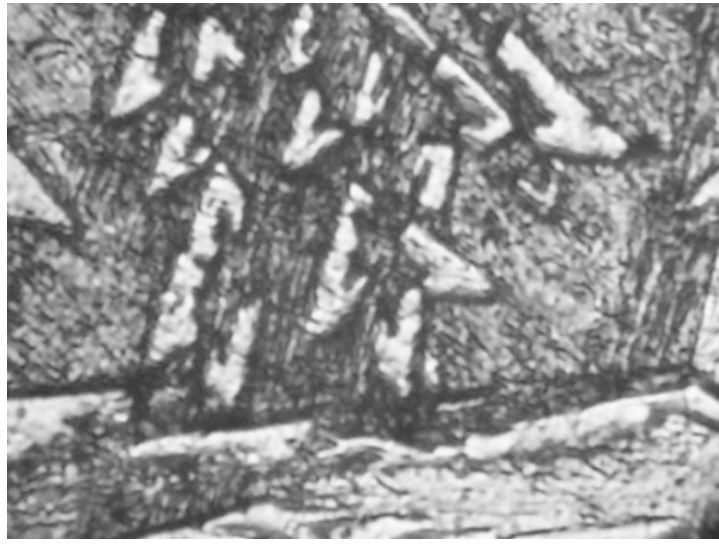

Fig. 1. Microstructure of VT3-1 titanium alloy after quenching; $\times 200$

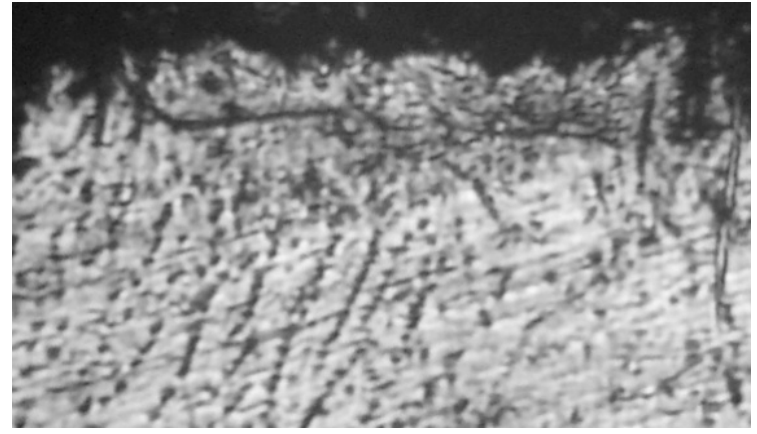

Fig. 2. Microstructure of borated alloy during 15 min.; $\times 200$

Similarly to structure, the texture can also affect the intensity of the titanium alloys boriding process.

Textured factor can be used to intensify boriding in the formation of hardened layers based either on titanium boride, or on a solid boron solution in titanium. This requires a dominant crystallographic orientation of the surface provided by the pre-treatment methods.

Surface hardening of the alloys' layers after boriding occurs due to formation of the borated layer with the well-developed boride and diffusion transitional zones.

When boriding duration increases from 30 to 120 minutes, boride and diffusion zones are increased due to greater penetration of atomic boron deep into the alloy, as well as to the formation and growth of increasingly more amount of borides and increase of the diffusion zone (Fig. 3, 4).

It is well known, that service properties of borated products depend primarily on thickness, structure and properties of the boride zone. However, the transition zone also significantly affects the performance of borated components (Fig. 5).

Thickness of the transition zone, the chemical composition and structure determine the distribution of residual stresses, bonding strength of boride layers with base metal, its susceptibility to chipping, conditions of fatigue cracks formation, possibility of a layer displacement. Therefore, influence of the transition zone structure, which consists of a mixture of phases $\alpha+\mathrm{TiB}$, on these properties should be considered when selecting an alloy and saturation mode.

Analysis of the impact of the boriding exposure time on the change of microhardness and thickness of the diffusion layer. Hardness on the surface of the borated sample (VT3-1 titanium alloy), under the developed technology of chemical-thermal treatment, reaches the value of $30 \mathrm{GPa}$, and in the diffusion zone it drops down to $25 \mathrm{GPa}$. This is due to a change of the phase composition of the titanium boride layer. The results of the analysis conducted have shown that the intensive growth of titanium borides layer thickness (from 25 to 100 microns) is observed at the increased duration of boriding from 15 to 60 minutes. 


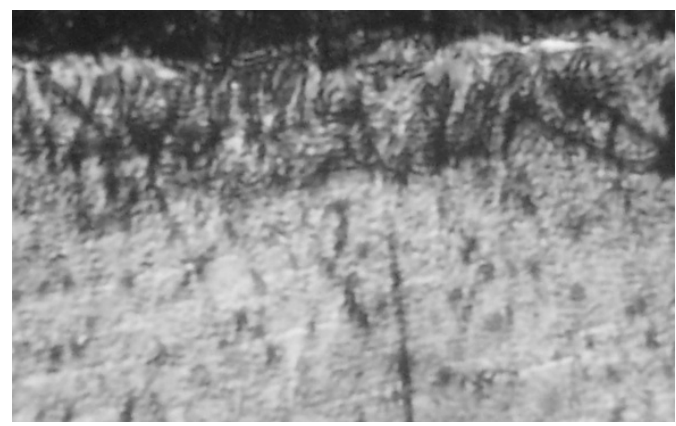

$a$

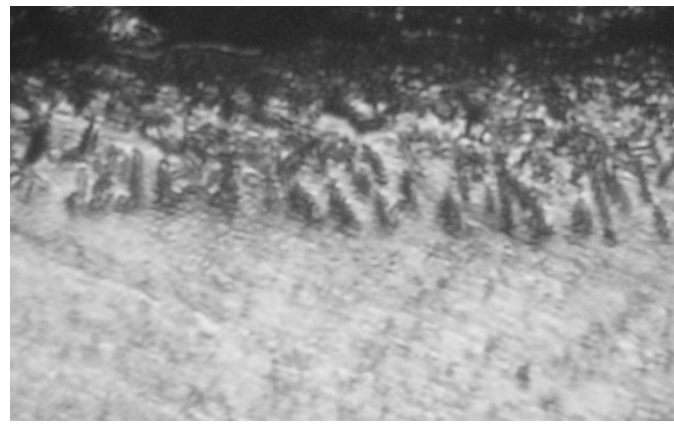

$b$

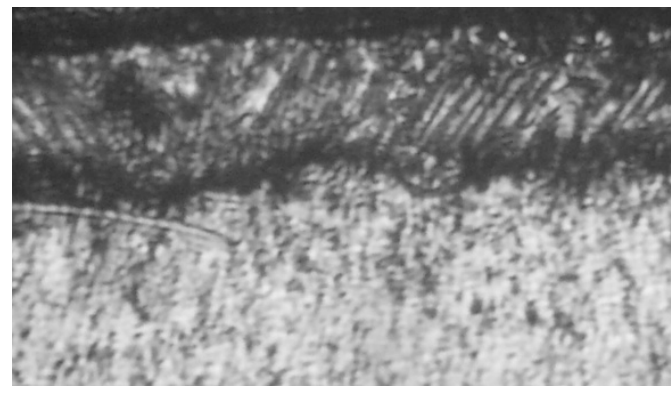

$c$

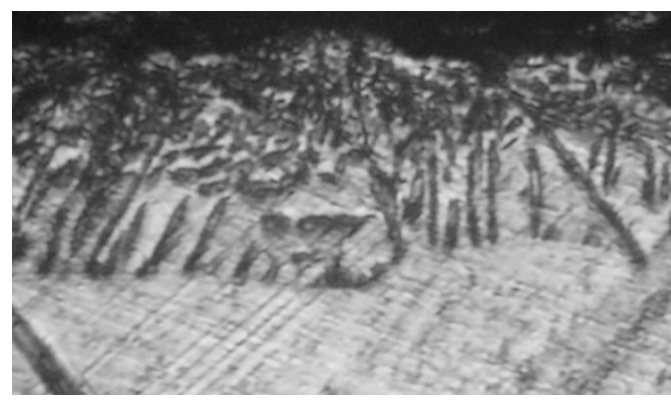

$d$

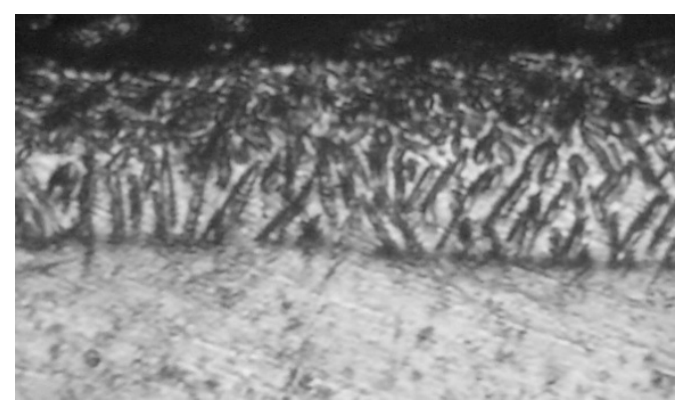

$e$

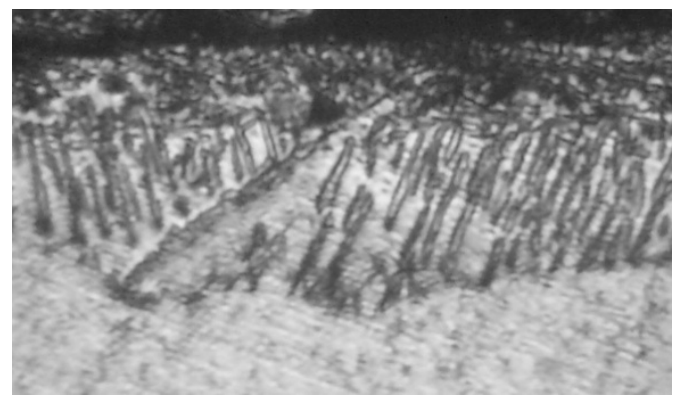

$f$

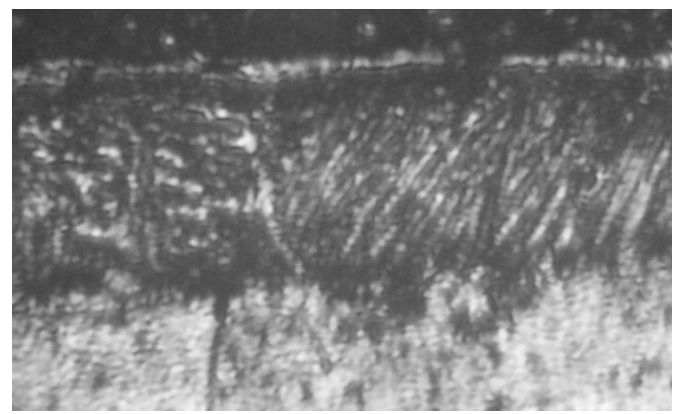

$g$

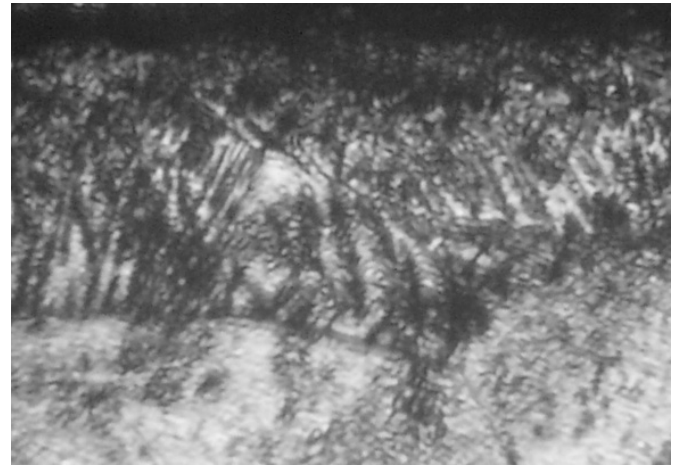

$h$

Fig. 3. Microstructure of VT3-1 titanium alloy after boriding at $900{ }^{\circ} \mathrm{C}$ during $30 \ldots 120 \mathrm{~min}$ : a $-30 \mathrm{~min}$;; $b-35$ min.; $c-40$ min.; $d-45$ min.; $e-60$ min.; $f-75$ min.; $g-90$ min.; $h-120$ min.; $\times 200$ 

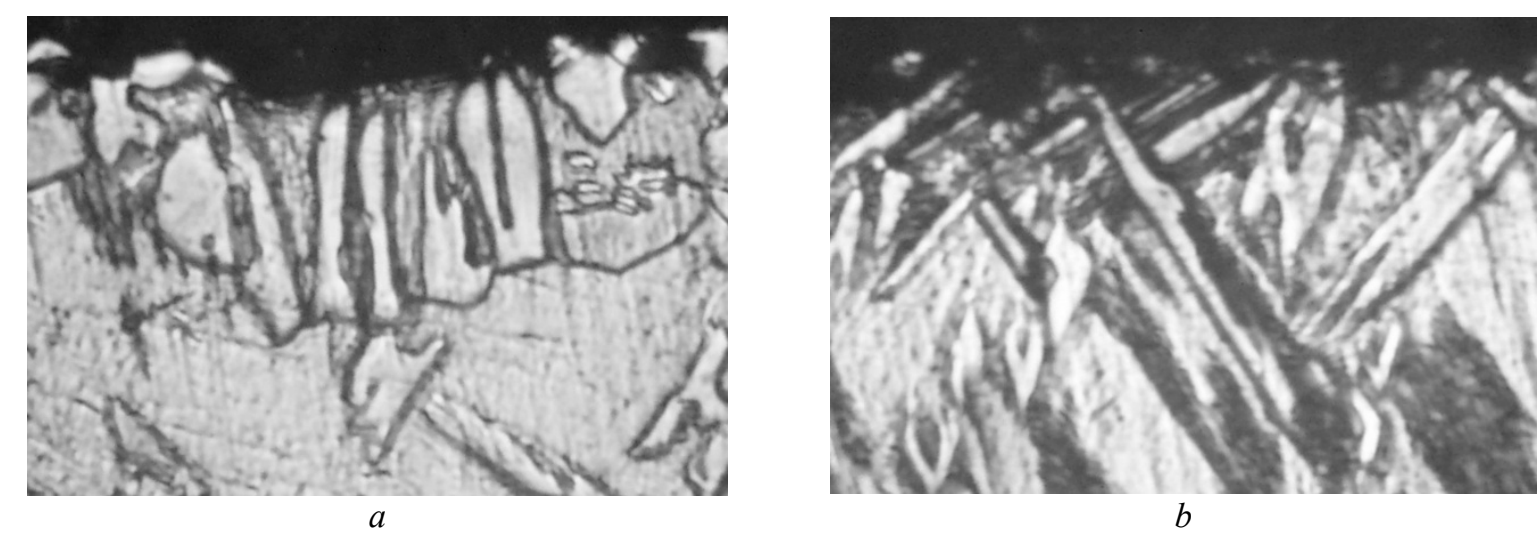

Fig. 4. Microstructure of VT3-1 titanium alloy after boriding at $900^{\circ} \mathrm{C}: a-30$ min.; $b-60$ min.; $\times 500$
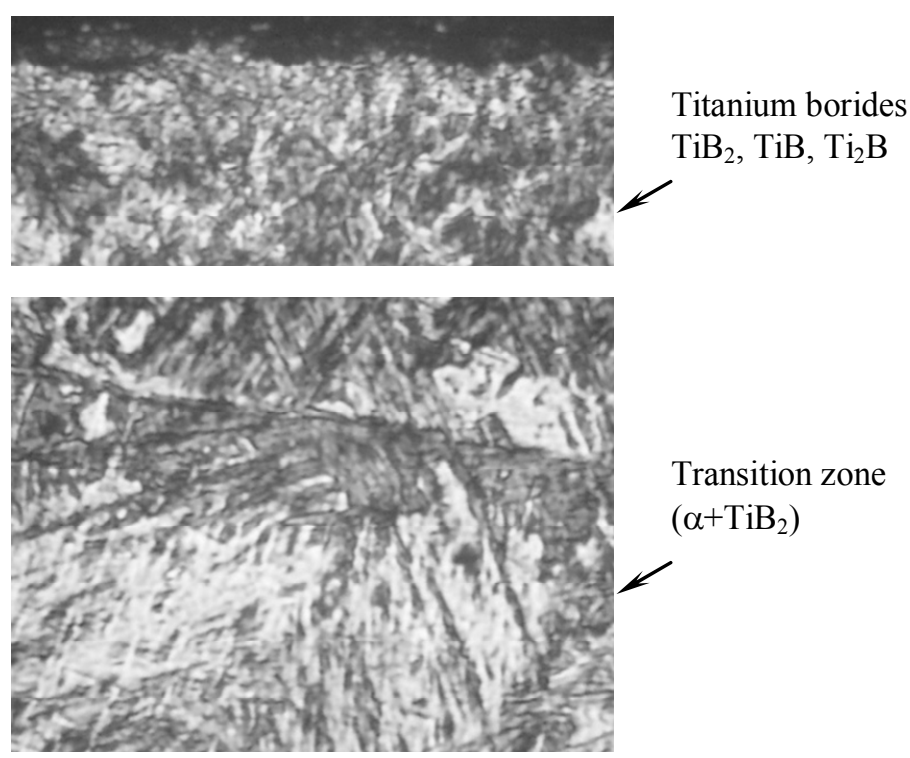

Fig. 5. Microstructure of VT3-1 titanium alloy after boriding at $900^{\circ} \mathrm{C}$ during 2 hours; $\times 350$

A further increasing the duration of treatment up to 2 hours leads to a slower growth of diffusion layers - 115 microns per 1,5 hours of boriding and 123 microns per 2 hours.

Results and Discussion. It was shown that boriding of paste compounds allows obtaining the surface hardness within $30 \ldots 29 \mathrm{GPa}$ and with declining to $27 \ldots 26 \mathrm{GPa}$ in layer to the transition zone (with total thickness up to $110 \mu \mathrm{m}$ ) owing to changes of the layer phase composition where $\mathrm{Ti}_{2} \mathrm{~B}$, $\mathrm{TiB}$, $\mathrm{TiB}_{2}$ titanium borides are formed. The increasing of chemical-thermal treatment time from 15 minutes to 2 hours leads to thickening of the borated layer $(30 \ldots 110 \mu \mathrm{m})$ and transition zone $(30 \ldots 190 \mu \mathrm{m})$. Due to usage of nanodispersed boric powder, the boriding duration is decreasing in $2 \ldots 3$ times. This allows saving time and electric energy. The developed optimal mode of boriding the VT3-1 titanium alloy allows obtaining the required operational characteristics and to combine the saturation of the surface layer with atomic boron and hardening.

\section{Література}

1. Lütjering, G. Titanium / G. Lütjering, J.C. Williams. — Berlin; New York: Springer, 2003. - 379 p.

2. $\mathrm{Li}, \mathrm{C}$. Improving the surface hardness and wear resistance of $\mathrm{Ti}_{3} \mathrm{SiC}_{2}$ by boronizing treatment / C. $\mathrm{Li}$, M.S. Li, Y.C. Zhou // Surface \& Coatings Technology. — 2007. — Vol. 201, Issue 12. — PP. 6005 - 6011. 
3. Munro, R.G. Material properties of titanium diboride / R.G. Munro // Journal of Research of the National Institute of Standards and Technology. - 2000. - Vol. 105, Issue 5. - PP. 709 - 720.

4. Atar, E. Characteristics and wear performance of borided Ti6Al4V alloy / E. Atar, E.S. Kayali, H. Cimenoglu // Surface \& Coatings Technology. — 2008. — Vol. 202, Issue 19. — PP. 4583 - 4590.

5. Aich, S. TiB whisker coating on titanium surfaces by solid-state diffusion: Synthesis, microstructure, and mechanical properties / S. Aich, K.S. Ravi Chandran // Metallurgical and Materials Transactions A. 2002. - Vol. 33, Issue 11. - PP. 3489 - 3498.

6. Basu, B. Processing and properties of monolithic $\mathrm{TiB}_{2}$ based materials / B. Basu, G.B. Raju, A.K. Suri // International Materials Reviews. - 2006. - Vol. 51, Issue 6. - PP. 352 - 374.

7. Вплив температури на поверхневе зміцнення титанових сплавів при контактному насиченні 3 аморфного бору у вакуумі / І. Погрелюк, В. Федірко, 3. Сірик, О. Самборський // Вісник ТДТУ. 2009. - Т. 14, № 1 . - С. $28-33$.

8. Притула, А.О. Взаємодія аморфного бору з титановими сплавами у газовому кисневмісному середовищі / А.О. Притула, І.М. Погрелюк, В.М. Федірко // Фіз.-хім. механіка матеріалів. — 2006. T. 42, № 5 . - C. $30-34$.

\section{References}

1. Lütjering, G., \& Williams, J.C. (2003). Titanium. Berlin; New York: Springer.

2. Li, C., Li, M.S., \& Zhou, Y.C. (2007). Improving the surface hardness and wear resistance of $\mathrm{Ti}_{3} \mathrm{SiC}_{2}$ by boronizing treatment. Surface \& Coatings Technology, 201(12), 6005-6011. DOI:10.1016/ j.surfcoat.2006.11.008

3. Munro, R.G. (2000). Material properties of titanium diboride. Journal of Research of the National Institute of Standards and Technology, 105(5), 709-720. DOI:10.6028/jres.105.057

4. Atar, E., Kayali, E.S., \& Cimenoglu, H. (2008). Characteristics and wear performance of borided Ti6Al4V alloy. Surface \& Coatings Technology, 202(19), 4583-4590. DOI:10.1016/j.surfcoat. 2008.03.011

5. Aich, S., \& Ravi Chandran, K.S. (2002). TiB whisker coating on titanium surfaces by solid-state diffusion: Synthesis, microstructure, and mechanical properties. Metallurgical and Materials Transactions A, 33(11), 3489-3498. DOI:10.1007/s11661-002-0336-6

6. Basu, B., Raju, G.B., \& Suri, A.K. (2006). Processing and properties of monolithic $\mathrm{TiB}_{2}$ based materials. International Materials Reviews, 51(6), 352-374. DOI:10.1179/174328006X102529

7. Pohrelyuk, I., Fedirko, V., Siryk, Z., \& Samborskyi, O. (2009). Influence of the temperature on the surface hardening of titanium alloys at the contact saturation from the amorphous boron in vacuum. Scientific Journal of The Ternopil National Technical University, 14(1), 28-33.

8. Prytula, A.O., Pohrelyuk, I.M., \& Fedirko, V.M. (2006). Interaction between amorphous boron and titanium alloys in a gaseous oxygen-containing medium. Materials Science, 42(5), 601-606. DOI:10.1007/s1 1003-006-0122-5 